\title{
Revisiting the Balkan Crisis: A Un Question; The European Connection and the Us Solution
}

\author{
Jackson Nyamuya Maogoto
}

\begin{abstract}
The more fundamental decision for the States of the intemational community, however, was whether to make the concessions necessary to create an effective international mechanism against the background of States insisting upon preserving the totality of their sovereign prerogatives, if such a view had held sway, no effective intemational criminal tribunal could have been created.
\end{abstract}

\section{Introduction}

In the early 1990s, while Westem leaders were still congratulating themselves over the end of comminism and the fall of the Soviet empire, the security structure that helped bring about those events began to come apart. Less than two years after the fall of the Berlin Wall, the structure of intemational law was under threat and appeared to be crumbling. It took a vicious war in Croatia in 1991 to stir public interest and the brutal war in Bosnia and Herzegovina to amplify the alarm bells for international action though it would have been sounded a good deal earlier. The lack of a systematic enforcement regime in the five decades since World War II contributed to the lack of respect for the legitimacy of international criminal and humanitar- ian law, and even to a degree of cynicism about it. States and individuals had come to regard international criminal and humanitarian law as more of a moral code of conduct than binding international obligations on States and individuals. No prosecutions occurred at the intemational level during the Cold War. With this failure at the intemational level, the key juridical moments of international criminal law were confined to the domestic circuit.'

The demands for legal process in the 1990 s witnessed the establishment of two ad hoc intemational criminal tribunals to try persons for the deaths of hundreds of thousands. The world community had determined that the inner workings of political censure and threats

\footnotetext{
'See generally Gerry Simpson,"Didactic and Dissident Stories in War Crimes Trials", 60 Alberta Law Review 801 (discussing the trials of Eichmann, Demanjunk, Barbie, Polyukhovic, Preibke, Touvier and others, 1997).
} 
of politicall, 'economic, and military retaliation cannot mend a rift in the rule of law as large as the one created by the actions of international outlaws and that the failure of international criminal and humanitarian law was in large part due to the lack of an international penal regime. Deterrence would only be secured by the certainty of punishment through trial and impunity for human rights atrocities curbed by legal process. The creation of the international criminal tribunal for the former Yugoslavia-a half century after the Nuremberg and Tokyo trials were held-revived hopes that in the postCold War era, crimes under international law can be deterred through international penal process.

This Article examines the conflict in the former Yugoslavia which gave birth to the International' Criminal Tribunal for the former Yugoslavia (ICTFY). The ICTFY' established the beginning of a new pattem in the genuine international implementation of intemational criminal and humanitarian law and the move back to the international model inaugurated at Nuremberg which had in the Cold War era been boldly supplanted by national prosecutions. The Article seeks to show that even this ad hoc tribunal was the by-product of international realpolitik. It was born out of a political desire to redeem the international community's conscience rather than the primary commitment of the international community to guarantee international justice. The ad hoc tribunal was established after ef- forts to reach political settlement had proved futile and had in fact shielded the bellicose Serbs from firm and decisive international action, allowing them to further their nationalist agenda at the expense of other entities of the Yugoslavian federation. The ICTFY was not established because of the primary view by the UN or the powerful States that control it over the intrinsic value on punishing war criminals or upholding the rule of law but rather the shame that resulted from a misguided conception that the Balkan crisis would be effectively resolved through a political settlement.

\section{Re-awakening International Penal Process}

The International Tribunal for the Prosecution of Persons Responsible for Serious Violations of International Humanitarian Law Committed in the Territory of the Former Yugoslavia Since 1991, as it is officially called, was established by the United Nations Security Council in May 1993. In an unprecedented decision by the Security Council, the tribunal was established as an enforcement measure pursuant to Chapter VII of the UN Charter. ${ }^{2}$ Its creation was essentially prompted by two considerations. First, by 1993, it had become obvious that the parties to the Yugoslav conflict were unwilling, and in the case of Bosnia and Herzegovina, unable to bring to justice persons responsible for the egregious crimes that were

\footnotetext{
${ }^{2}$ Chapter VII allows the United Nations to use military force and act in areas otherwise reserved to the domestic jurisdiction of States. United Nations operations in Iraq, Somalia, and Haiti were all authorised under Chapter VII. See SC Res. 678, UN SCOR, 45th Sess., Res. \& Dec., at 27, UN Doc. S/INF/46.(1990); SC Res. 794 , UN SCOR, 47th Sess., Res. \& Dec., at 63, UN Doc. SIINF/48 (1992); SC Res 841, UN SCOR, 48th Sess., Res. \& Dec., at 119, UN Doc. S/INF/49 (1993).
} 
taking place. Second, by establishing the Tribunal, the Security Council hoped to deflect criticism for its reluctance to take mose decisive action to stop the bloodshed in the fomer Yugoslavia. In both political and legal terms the Council's action was groundbreaking. With the Cold War over and with it the crumbling of the ideological barrier between 'East' and 'West' it became possible for the Security Council to reach political agreement on a measure that would have been unthinkable only four years earlier. ${ }^{3}$

Brutal wars are, of course, not new and there were conflicts prior to Yugoslavia's dissolution that could have as equally justified the establishment of war crimes tribunals. The persecutions committed in Cambodia under Pol Pot, to name one example, did inspire talk of establishing a criminal tribunal, but not until the summer of 1997.4 Why, then, did the international community react so strongly to the conflict in the former Yugoslavia? ${ }^{5}$ There are various possible reasons for the reaction. First, there is the resemblance of the Serb-run detention camps - to Nazi Germany, with recollections of the establishment of the Nuremberg Tribunal following the war. Second, widespread media coverage focused attention on the atrocities being committed in the region and the repeated failure of the intemational community to induce a negotiated peace between the waring parties. ${ }^{6}$ A third possible reason is political-with the col- lapse of the Cold War and renewed interaction among the Security Council members individually, there was new willpower, as well as the ability to effect political change by a United Nations keen to carve out a much broader role by acting as a watchdog over international disputes, peacemaker and peacekeeper.

Not without controversy, the international community, with the Security Council at its helm, decided that the establishment of an international tribunal empowered to prosecute persons responsible for serious violations of intemational humanitarian law committed in the territory of the former Yugoslavia since 1991 was a worthy precedent to set, worthy even to the extent of subjugating the sovereignty of the States involved. The ICTFY while welcomed, its legal basis was not, owing to a number of factors all of which in one way or another are linked to considerations of State sovereignty. But in the end, the horrors of the Balkan conflict and the international outrage they generated prevailed, with no State (except the Yugoslav Republics) being bold enough to object strenuously and thus appear to be actively blocking the quest for intemational justice and thus subordinating the noble idea to the vagaries of realpolitik.

\section{Situational Background and Develop- ment of the Balkan Conflict}

In 1946, following the victory of Tito's forces and the ascent to power of the Communist Party

\footnotetext{
${ }^{3}$ Jelena Pejic, "Panel il: Adjudicating Violence: Problems Confronting International Law and Policy on War Crimes and Crimes Against Humanity; The Tribunal And The iCC: Do Precedents Matter?" 60 Albany Law Review 841, (1997). .

"See "The Pol Pot Riddle," The Economist. 28 June 1997 at 47.

${ }^{5}$ Virginia Morris \& Michael P. Scharf, The Intemational Criminal Tribunal for Rwanda. (Vol. 1) 17, 1998.

'Ibid at 17.
} 


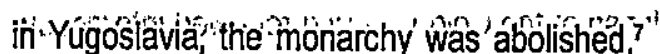

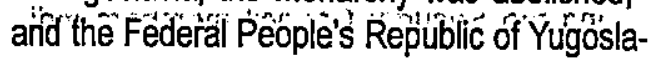
via was reconsstitúted as a federation. The component five States of Croatia, Macedonia, Montenegro, Serbia and Slovenia, each contained a majority of the ethnic group as reflected in the name of each State. A sixth province, Bosnia-Herzegovina, whose borders reflected administrative lines drawn by the former Ottoman and Austro-Hungarian empires, was home mainly to Croats, Serbs and Muslims (who had converted to Islam during Ottoman rule). In the 1970's, certain other divisions were created, such as the region of Kosovo and the Province of Vojvodina, autonomous units within the Yugoslav federation. ${ }^{8}$

Tito had suppressed resurgent nationalist ambitions of ethnic groups consistently during his rule from 1946 until his death in 1980. With Tito's death, the country was now ruled by a hopelessly inefficient collective presidency that Tito had devised, comprising representatives from each of the six republics and the two autonomous regions. With no leader possessed of Tito's charismatic authoritarianism, Serb nationalists,-many of them Communist Party members began grumbling forcefully that Tito's national policy was designed to fragment
Yugoslavia, dilute Serb dominance, and make it easier for Tito to rule unchallenged. This view was championed by Ivan Stambolic, the Communist Party leader of Serbia (the largest and most powerful of the republics). ${ }^{9}$ Not long after Serb nationalistic sentiment gathered momentum, individual republics ever resentful of the might of Serbia, began to agitate for greater autonomy from the central government heralding the beginning of virulent nationalism.

In 1987, Slobodan Milosevic rose to power in Serbia on the wave of crude nationalistic meto. ric. ${ }^{10}$. Though possessing Tito's determination to rule unchallenged, he lacked Tito's personal authority and mastery at balancing ethnic interests and thus maintaining the delicate ethnic balance in the federation. His initial goal of taking over Tito's creation appeared increasingly impossible as the seething cauldron of historical ethnic hatreds among the Croats, Serbs, Bosnian Muslims, and Slovenes transformed into keen nationalistic. fervour in the respective republics. Late in 1989 , with growing nationalism in the various Yugoslav republics, Milosevic decided that in the event of the break-up of Yugoslavia, he would endeavour to win most of it for himself and thus was born the idea of

${ }^{7}$ Yugoslavia, created in 1918 from the Kingdoms of Serbia, Montenegro and portions of the defunct AustroHungarian empire, was known as the 'State of Serbs, Croats and Slovenes' until it was renamed 'Yugoslavia' in 1929, and in 1974, the 'SocialistFederal Republic of Yugoslavia'. Prior to the Second World War, Yugoslavia was ruled by King Alexander I as a unitarist monarchy.

- ${ }^{8}$ Morris \& Scharf, above $n 5$ at. 422.

${ }^{9}$ Dusko Doder \& Louise Branson, Milosevic: Potrait of a Dictator (1999) p. 27. See also Roger Thurow. "Tito's Legacy: Political Drifting, An Economy in Chaos Prevail in Yugoslavia; Question is Whether Nation Will Turn More to Soviets Out of Economic Need; Sharpening Ethnic Rivalries." Wall Street Joumal. May 1986. available in 1986 WL-WSJ 258991.

${ }^{10}$ Doder \& Branson, Ibid., at 35-62. 


\section{'Greater Serbia'."}

In a Slovenian referendum on the question of secession from Yugoslavia, held in December 1990, an overwhelming majority of voters opted for independence. A declaration of independence was announced on 8 May 1991, followed by the necessary amendments to the operative constitutional law on 25 June. In a bid to force the Slovenes to rescind the declaration of independence, Serb President Slobodan Milosevic ordered the invasion of Slovenia by the Yugoslav Army (JNA). ${ }^{12}$ The YugoslavSlovene War, the first in a series of wars in the soon to be crumbling federation of Yugoslavian States started on 27 June. Within seventy-two hours, a 'troika' of EC Foreign Ministers (those of Italy, Luxembourg and the Netherlands) mounted two rapid missions to Yugoslavia. ${ }^{13}$ The EC-negotiators received repeated promises of cease-fires, but violence continued to erupt as federal troops continued to consoli- date their positions in Slovenia. After several failed cease-fires, a political settlement was reached resulting in the Brioni Agreement that effectively gave Slovenia its independence. The Yugoslav-Slovene War was short and by standards of what was to come next, almost a lark: ${ }^{14}$ Within ten days, after light casualties and the negotiation of the Brioni Agreement, Milosevic ordered the JNA to withdraw. The secession of Slovenia from the Federal Republic of Yugoslavia opened the door to several other secessionist claims, unleashing many long dormant territorial disputes among the ethnic and religious groups of Yugoslavia and reviving the determination on the part of certain groups to settle old scores..$^{15^{\circ}}$

Croats living in the Republic of Croatia declared their independence from the rump Federation of Yugoslavia on 16 March 1991. Shortiy after Croatia's declaration of independence, the

"1 bid., àt 63-83.

"Marcus Tanner, "Slovenia is at War," The Independent, 28 June 1991 at 1.

${ }^{13}$ The troika was composed of the Foreign Minister of the state holding the presidency, and his predecessor and successor as President of the EC Council. It operates within the framework of 'European Political COoperation' or EPC, in accordance with title ll of the Single European Act, 17 and 28 February, 1986, reprinted in 25 ILM503 (1986). EPC promotes the adoption of common positions and common actions by the Member States on foreign policy issues. See P J G Kapteyn \& P V Van Themaat. Introduction to the Law of the European Communities After the Coming Into Force of the Single European Act, 1989, 2nd ed. p. 23-24. Following the practice of the press releases of the European Commission, EPC activities are considered part of the general framework of the Community and are therefore subsumed under the abbreviation ' $E C$.' On midnight of 30 June, the rotating presidency of the EC passed from Luxembourg to the Netherlands and shortly afterwards EC govemments sent a third mission, this time composed of senior diplomats from Luxembourg, the Netheilands and Portugal, to see if they could help monitor a new and durable cease-fire in Slovenia and a withdrawal of Federal forces.

${ }^{14}$ Richard Holbrooke, To End A War, 1998, p. 29.

${ }^{15} \mathrm{Arguably}$, the disintegration of Yugoslavia was later accelerated by premature recognition on the part of certain influential members of the international community of Slovenia as an independent State. On 15 January 1992, the twelve members of the European Community $(E C)$ recognised Slovenia. 
Serb-dominated JNA stormed Croatian territory in an attempt to crush the Croats bid for independence. This act of aggression, spurred by communist-run Serbia's quest for all of Yugoslavia's 8.3 million Serbs to live in'a 'Greater Serbia', ${ }^{16}$ was the catalyst that launched the bloody SerbCroat War, the second in a series of conflicts that was to render the Balkans a theatre of war. Unlike Slovenia which had almost no Serbs, Croatia had a large Serb population and Milosevic was determined to secure all teritory inhabited by Serbs pursuant to the 'Greater Serbia' idea, hence the vicious invasion by a Yugoslav Amy that had now become a Serb army fighting for Serbs.

Neither the EC nor the CSCE was ready for the new crisis in Yugoslavia resulting from the Serb invasion of Croatia. The members of the European Community were just about to start the final phase of negotiations leading up to the Maastricht summit of December 1991. The strengthening of co-operation in foreign policy among the members of the Community and the transformation of this co-operation into a common foreign policy were controversial issues. Problems arose over what kind of international response to the bloody Serb-Croat War was permissible with or without consent of the parties or of Yugoslavia. Milosevic strongly insisted on non-interference as Europe discussed military intervention in the summer of 1991, and had considerable support among, for example, many Third World countries. ${ }^{17}$ A rather confusing debate conceming the meaning of Article $2(7)$ of the UN Charter-the principle of nonintervention-seriously delayed and weakened the initial response to the crisis. Coupled with this interpretational conundrum at the international level was the fact that the Council for Co-operation and Security in Europe (CSCEthe security arm of the EC) was just being transformed from a mechanism dedicated to maintaining crisis stability in Cold War Europe to a standing organisation capable of offering procedures akin to collective security within Europe meaning that the regional effort was hamstrung by lack of concrete ideas on how best to react. ${ }^{18}$ The Soviet Union, concerned about the precedent of UN intervention could set for future conflicts in Yugoslavia, insisted on non-interference. Even the UN Secretary-General was sceptical since, he argued, this was

${ }^{16}$ Jelana Pejic. "Yugoslavia: Time is Running Out." InterPress Service. 25 June 1998 available in LEXIS, Nexis Library, Curmt File. The Serbian Democratic Party (SDS) stated that it had nothing against Croatia's and Slovenia's independence, 'provided that Serbs have the right to live in one country, be it Yugoslavia or Serbia.' Ibid. Of the 4.68 million people in Croatia, $85 \%$ are ethnic Croats and $11.5 \%$, or about 600,000 , are ethnic Serbs. Marc Weller. "The International Response to the Dissolution of the Socialist Federal Republic of Yugoslavia," 86 American Joumal of Intemational Law 569 (providing a thorough delineation of the events comprising Yugoslavia's dissolution through mid-1992).

${ }^{17}$ Age Eknes. "The United Nations' Predicament in the Former Yugoslavia." in Thomas G Weiss (ed). The United Nations and Civil Wars. (1995). p. 114.

${ }^{18}$ The original, non-binding CSCE Final Act of 1975 affirmed, in Principle I, the right of every State to juridical equality, territorial integrity, freedom and political independence with the protection of the territorial integrity of States, defined in greater detail in Principle IV. Further the reference to territorial integrity confirms an obligation directed at States, but not at peoples, alluding to an obligation of non-intervention further reinforced in Principle VI of the Final Act. It was perceived by the Serbian-dominated central authority as carte blanche for the forcible implementation of its goals to reunify the federation and consolidate its leadership within it. 
an internal Yugoslav matter. At this time, many officials suggested that the Yugoslav situation could potentially engulf the country in a brutal civil war if conflict was not immediately suppressed, and that the establishment of a peacekeeping force in the troubled region was the best chance to prevent open war: ${ }^{19}$ Despite these prophetic warnings, the SecretaryGeneral's decision that the situation wàs handsoff was likely prompted more by the belief that any attempt at $U N$ action would be vetoed by the Soviet Union. ${ }^{20}$ The notion that the international community found the decision of UN involvement beyond their reach calls into question just how far the UN has succeeded in overcoming the hamstrung Cold War era.

As violence in Croatia escalated over the next several months, the European Community assumed a monitoring and negotiating role in an effort to bring peace to the region and prevent an all-out war in the Yugoslav federation. ${ }^{21}$ The European Community Monitor Mission (ECMM) made up of personnel from the twelve EC members, served as a channel of communication between opposing forces to organise cease-fire arrangements. ${ }^{22}$ However, the attempt to promote agreement among factions separated by ethnic hatred and mistrust proved futile, ${ }^{23}$ as numerous cease-fires failed to take hold, and violence increased in Croatia due to active support of Croatian-Serb militia by the JNA. ${ }^{24}$ The EC efforts were plagued by the parties' irreconcilable demands, confilicting chains of command on both sides, dissension over the withdrawal of armed forces from regions in Croatia; and security considerations with re-

${ }^{10}$ Marc Fisher, "Slovenia Nears Independence as Croatia Faces Civil War:" p. 6-7 'Leaders Said to See Croats Destined for War.' Washington Post. 20 July 1991 at A1. A senior German official was quoted as saying 'without a peacekeeping force, Croatia is destined to suffer civil war.' Ibid.

${ }^{20}$ The obstacle is a clear Soviet message that Moscow will veto any attempt to use UN forces to settle an internal Yugoslav dispute.... the Soviets will resist any move that could set a precedent for 'intemalising' nationalist conflicts such as those that plague Soviet President Mikhail Gorbachev's government. Ibid.

${ }^{21}$ United Nations Year Book (1991) 214 (describing the EC's introduction into the conflict and peacekeeping efforts thereafter). An EC Ministerial Troika mission (ECMM), dispatched to Yugoslavia to facilitate a truce and the retum of all forces to their previous positions, worked out a cease-fire agreement on 31 July 1991, with the aid of the Conference on Security and Co-operation in Europe (CSCE). Jonathan Landay, Presidency Agrees on Proposed Truce Plan, UPI, 31 July 1991, available in LEXIS, Nexis Library, UPI File. See also. "Policing Yugoslavia." Times (London); 31 July 1991.

${ }^{22}$ See Reeport of the Secretary-General Pursuant to Paragraph 3 of Security Council Resolution 713, Doc S/23169 (1991) 6.

${ }^{23}$ Andrew Clark, "Yugoslavia: Fragile Cease-fire Hoids in Croatia," Australian Financial Review, 10 October 1991.

${ }^{24}$ Report of the Secretary-General, UN Doc. S/22991 (1991). Negotiations were attempted at an ECsponsored peace conference in Brussels on 27 August 1991. Ibid. Moving to The Hague, Netherlands, the Conference on Yugoslavia convened on 7 September 1991, with the goal of resolving a peaceful settlement of the conflict. See generally Weller, above $n 16$ (outlining the EC's response to the outbreak of fighting among Croats and Serbs). 
spect; torthe; non:military, unarmed EGMM:25. Assregionalneggotiations undertakenįiniconformity with Ghapter VIII of the UN :Charter ${ }^{26}$ failed to restore peace, the UN Security Council responded to calls for reinforcement of the EC Mission by convening its first meeting to assess the situation on 25 September 1991, four months after Croatia's declaration of independence. ${ }^{27}$

\section{International Response through Politj- cal Process: The Disjointed Efforts of the EC and UN}

There were never any easy options for the former Yugoslavia. The war posed a stronger challenge to norms and principles among concemed govemments than a classical strategic threat would have done. The use of armed force, even collectively; to influence the course of the conflict was therefore likely to generate contradictory pressures and unsatisfactory results. From the initial stages, it was evident that the major actors or govemments had varying inclinations or interests, and this created tensions in the regional organisations as well as in the UN. ${ }^{28}$ The result was disaster. Support for maintaining the 'unity' and 'territorial integrity' of Yugoslavia worsened the situation, delaying international pressure on the Serbs 'to undertake timely reform toward a loose confederation while intensifying internal pressures for a complete break-up. ${ }^{29}$

As the $\mathrm{EC}$ was the only organisation involved first-hand in the developing crisis, it should have been the first to apprise the international community that the dissolution of Yugoslavia was

${ }^{25}$ October 1991 Report, above $\mathrm{n} 22$.

- ${ }^{26}$ Article 52(2) provides that Member States entering into regional arrangements 'shall make every effort to achieve pacific settlement of local disputes through such regional arrangements or by such regional agencies before referring them to the Security Council.' UN Charter Article 52(2).

${ }^{27}$ In response to letters from the international community requesting that the United Nations reinforce EC efforts due to the rapidly deteriorating situation in Yugoslavia, a meeting of the United Nations Security Council was convened on September 25, 1991. Letter of 19 September 1991, UNDoc. S/22903 (Austria); Letter of 19 September 1991, UN Doc. S/23053 (Canada); Letter of 19 September 1991, UN Doc. S/23057 (Hungary); Letter of 19 September 1991, UN Doc. S/23069 (Yugoslavia).

${ }^{28}$ See generally, Eknes, above $n 17$.

${ }^{29}$ Zbigniew Brzezinski, "Bombs and Blather: The Strategy Deficit; Can Clinton Find America's Missing Foreign Policy?" Washington Post. 17 January 1993. at C1. The United States led the initial call for respecting Yugoslavia's territorial integrity, qualifying this appeal, 'We particularly call upon the central government and the Yugoslav army to end the bloodshed, to exercise restraint and to commence negotiations immediàtely.' State Dept., 28 June 1991 (regular briefing by Margaret Tutwiler), available in Lexis, Nexis Library, Curnt File. Additionally, support for maintaining the 'territorial integrity' of the Yugoslav federation was voiced by the EC and its members, and the Conference on Security and Co-operation in Europe (CSCE). Weller, above $n 18$ at 570. Within days of the initial independence declarations, the Serb-dominated Yugoslav govemment outlawed Slovenia's and Croatia's independence declarations and ordered the federal army to seize control of the borders with Slovenia. World News Summary, Agence France Presse, 27 June 1991. The federal defence ministry stated the army would 'take all necessary steps' to defend Yugoslavia's territorial integrity. Ibid. 
inevitable, and that appeals to preserve Yugoslavia's unity were in effect reinforcing the Serb-dominated government and army's efforts to quash the republics' independence. ${ }^{30}$ The initial policy of the EC of keeping Yugoslavia together was replaced by attempts to find compromise solutions, which in effect meant redrawing frontiers. Such an approach proved difficult on one main reason, the unwillingness of the parties to compromise on territory. ${ }^{31}$ Adding to this problem was the premature recognition by some European States of the independence of some of the breakaway States. The Europeans kept the UN out of Yugoslavia in the early stages. The EC's year-long solo efforts proved inadequate to negotiate a political settlement of the conflict in Yugoslavia. While the commitment of the EC to handle the crisis was meritorious, it was not realistic. The nature of the dispute sim- ply did not lend itself to simple negotiation of a solution. ${ }^{32}$ The US, still involved in the Gulf, insisted on the logic of the UN Charter and hence felt that the UN had no role to play unless regional attempts failed.

The initial ambivalent Security Council resolutions that sided with or punished the Serbs also served to undermine efforts that depended on all the parties' co-operation. ${ }^{33}$ In its first action concerning the Yugoslav conflict, the Security Council displayed its incomplete understanding of the underpinnings of the crisis. At its first meeting to address the Yugoslav crisis, the Council unanimously adopted Resolution 713 , expressing 'deep concern' over the fighting in Yugoslavia, the heavy loss of life, and, in particular, the consequences for the border areas of neighbouring countries. ${ }^{34}$ As a remedy, the resolution called for the immediate implementa-

${ }^{30}$ Weller, above $\mathrm{n} 18$ at 570 . This policy of proclaiming territorial integrity, precluding internal attempts at secession, 'was perceived by the Serbian-dominated central authority as carte blanche for the forcible implementation of its goals to reunify the federation and consolidate its leadership within it.' lbid. at 572.

${ }^{31}$ Eknes,above $n 19$ at 115.

${ }^{32}$ Deep-seeded animosity and distrust, coupled with the absence of a central authority in Yugoslavia, foretold that the parties were not likely to simply talk through their differences. Without a peacekeeping force to bring order and stability to the region, the charged situation did not permit a negotiated settlement of political differences. While some regional organisations are outfitted to compliment negotiation efforts with the dispatch of peacekeeping forces, the EC is not equipped to resort to peacekeeping. Instead, the EC sent 'monitors' to the region that proved incapable of little more than observing the escalating violence. See Amy Lou King. "BosniaHerzegvina-Vance-Owen Agenda for A Peaceful Settlement: Did the UN Do Too Little, Too Late, To Support This Endeavour?"23 Georgia Joumal of International and Comparative Law 347 (1993), p. 368-369.

${ }^{33}$ Security Council Resolutions 713 (25 September 1991), 757 (30 May 1992), 781 (9 October 1992), 787 (16 November 1992). These resolutions covered economic and military sanctions and their implementation. See, The United Nations and the Situation in the Former Yugoslavia: Resolutions of the Security Council and Statements by its President, 25 September 1991-28 April 1995, (United Nations Department of Public information, 1995).

${ }^{34}$ SC Res. 713 , UN SCOR, 3009th mtg., UN Doc. S/23067 (1991). The Council unanimously adopted the five-nation draft proposed by Austria, Belgium, France, the USSR, and the United Kingdom. Ibid. The resolution noted that 'the continuation of this situation constitutes a threat to international peace and security', recalled the 
tion of a complete embargo on all deliveries of weapons and military equipment to Yugoslavia. ${ }^{35}$ Although meant to curb the escalating violence and cut off outside weapons support for the factions involved, the Council's action instead tipped the balance of power. It solidified the Serbs' already powerful military advantage, given their control over most of the country's amaments as. well as the federal army, and its position as the tenth biggest arms producer in the wordd. ${ }^{36}$ This move further exacerbated the situation, enabling the Serbs to overpower the Croats and Muslims due to their military advantage. Imposing an arms embargo neither deterred the fighting, nor quenched animosity; rather, this action fuelled the Bosnian Muslims' resentment of the UN's approach to the crisis, regarding the arms em- bargo as the removal of their ability to defend themselves against the well-armed Serbs.

After it became evident that the EC's efforts at political settlement were not proving effective as its brokered cease-fires collapsed one after another, the UN stepped in with the appointment of Cyrus R. Vance, former US Secretary of State as the Secretary-General's personal envoy to Yugoslavia. ${ }^{37}$ Stepping in amidst the EC-sponsored peace process and the tenth failed cease-fire in three months, Vance commenced a 'fact-finding' mission in Yugoslavia to sound out the parties on prospects for future negotiations. ${ }^{38}$ Although the Security Council did not act with respect to the Yugoslav conflict over the next two months, Vance maintained an active role at the request of the Secretary-General..$^{39}$ Embarking on two

principles 'enshrined in the Charter,' and stated in The CSCE declaration of September 3 'that no territorial gains or changes within Yugoslavia brought about by violence are acceptable, ' lbid.

${ }^{35} \mathrm{lbid}$. The resolution provided that under Chapter VII of the Charter, 'for the purposes of establishing peace and stability in Yugoslavia,' a general and complete embargo was to be implemented immediately by all States 'on all deliveries of weapons and military equipment to Yugoslavia until the Security Council decides otherwise.' I bid., p. 6.

${ }^{38}$ Nick Thorpe, "Yugoslavia: Croatia digs in for Long War," Observer. 13 October 1991 at 13. Bosnian Ambassador to the UN, Mohammed Sacirbey, stated that the balance of power between the Muslims and Serbs. was tipped such that the Muslims had 2 tanks, 24 artillery pieces, and no planes, while the Serbs had more than 300 tanks, 400 artillery pieces, and at least 60 planes. Remarks of Ambassador Mohammed Sacirbey Before the American Jewish Committee Ambassador's Forum Luncheon (22 October 1992), available in Lexis, Nexis Library, Currnt File.

${ }^{37}$ October 1991 Report, aboven 22 at 2. The appointment of Vance was the result of a September 25, 1991 Security Council resolution inviting then Secretary-General Javier Perez de Cueller to offer his assistance in peace- making efforts and to report back as soon as possible. 'Cyrus Vance to Visit Yugoslavia as UN Chief's Envoy', Reuters 9 October 1991. Vance served as Secretary of State for just over three years under US President Jimmy Carter, resigning in 1980 after opposing a decision to launch an armed rescue mission to free Americans being held hostage in Iran. lbid.

${ }^{38}$ October 1991 Report, above $\mathrm{n} 22$ at 3, 5. In addition, Vance attended sessions of the Conference on Yugoslavia at The Hague at the invitation of its chairman, Lord Carrington of Britain, and pursued contact with leaders of all factions involved in the Yugoslav conflict. Ibid. at 3.

${ }^{39}$ Action by the Security Councilis symbolised by the adoption of a resolution. Robert $E$ Riggs \& Jack C Plano, The United Nations: Intermational Organization and World Politics (1988), p. 84. 
subsequent missions to Yugosiavia in October and November 1991, Vance held discussions with the parties concerning the feasibility of deploying a UN peacekeeping operation in Yugoslavia, and arranged yet another cease-fire agreement. ${ }^{40}$ In Resolution 721, the Council endorsed Vance's efforts, although it would not consider a peacekeeping operation until the warring parties complied with previous agreements. ${ }^{41}$ Vance's efforts were solely targeted at ending the bloody Serb-Croat War, inspite of signs that the theatre of war was likely to expand as other States clamoured for independence.

In response to the so-called Vance Plan, in January 1992, the UN passed Resolution 749, which authorised the full deployment of a United Nations Protection Force (UNPROFOR) which was to be deployed in three UN Protected Areas. The Vance Plan defined the operation as the UN peacekeeping operation in Yugoslavia with an interim arrangement to create the conditions required for the negotiation of an overall settlement of the Yugoslav crisis. With UNPROFOR's establishment, the Security Council primarily expended its efforts to deal with the situation on the ground, enforcing, expanding, and reinforcing UNPROFOR's mandate to create the conditions of peace and security required for the negotiation of an overall settlement of the Yugoslav crisis. When the UN authorised the deployment of a peacekeeping force (UNPROFOR), it made no attempts to consolidate its efforts with the mediation efforts of the EC. This disjointed approach of handling the Yugoslav crisis, with the UN concentrating on 'peacekeeping,' while the EC struggled at 'peacemaking,' resulted in 'a host of mutually incompatible and haphazardly constructed policies,' which doomed both operations to failure. ${ }^{42}$

About two months after the deployment of UNPROFOR in Croatia, on 3 March 1992, Bosnia declared. itself an independent nation after a referendum in which $63 \%$ voted for the emergence of an independent Republic. Backed by Belgrade, Bosnian-Serbs demanded that the Bosnian govemment headed by President Alija izetbegovic withdraw its declaration of independence. Within a few days of the demand and refusal of the Bosnian government to withdraw the declaration, Bosnian-Serb nationalist militia, including some soldiers from the JNA, invaded parts of BosniaHerzegovina. Under Serbian Democratic Party leader Radovan Karadzic ${ }^{43}$ the Serb Republic was proclaimed with its administrative centre in

${ }^{40}$ The parties signed the Geneva Agreement, thereby agreeing to an unconditional cease-fire, on 23 November 1991. Letter Dated 24 November 1991 From the Secretary-General Addressed to the President of the Security Council, UN SCOR, UN Doc. S/23239 (1991). This agreement was the fourteenth thus far since the conflict began. UN Peacekeeping Operation for Yugoslavia in Question, Cease-fire Must First be Respected, UN. Chronicle, March 1992 at 72.

${ }^{41}$ SC Res. 721, UN SCOR, 3018th mtg., UN Doc. S/Res 721 (1991). Specifically, the Council would not consider the deployment of a UN peacekeeping operation until all parties fully complied with the November cease-fire agreement, which called for the removal of Croatian blockades of all JNA barracks and installations, and the immediate withdrawal from Croatia of blockaded military personnel and weapons, Ibid., p. 2.

${ }^{42}$ Jonathan Eyal. "United Nations: Blue Flag of Inconvenience-Former Yugoslavia." Guardian. 29 January 1993.

${ }_{43}$ In July 1996, Karadzic was indicted by the International Criminal Tribunal for the Former Yugoslavia. 
Pale. Well-armed Serbian militia were able to occupy, at some points, $70 \%$ of Bosnian ternitory. The Serbian leaders carried out a policy of 'ethnic cleansing' to try to rid the occupied territories of Bosnian-Muslims through a systematic policy of widespread massacres and other serious violations of human rights and humanitarian law, including mass deportations of civilian Muslims. ${ }^{44}$

In, June 1992, as the conflict intensified and extended to Bosnia and Herzegovina, the Security Council acted in an attempt to deal with escalating violence and the task of facilitating humanitarian assistance to the besieged regions ${ }_{1}{ }^{45}$ by enlarging UNPROFOR's mandate and strength in order to ensure the security and functioning of the airport at Sarajevo, and the delivery of humanitarian assistance to that city and its environs. However the Council deferred the task of negotiating an overall political settlement of the conflict to the European Community, urging the three communities in Bosnia to participate in the ongoing discussions. ${ }^{46}$ Thus, the EC, acting under the auspices of the Conference on Yugoslavia since September 1991, continued talks with the three factions to achieve a settlement and added the job of negotiating constitutional arrangements for Bosnia-Herzegovina. Because Vance's peacekeeping plan, proposed in the midst of the Serb-Croat conflict, primarily dealt with the facilitation of UNPROFOR for Croatia, the Council made only sporadic mention of the Vance/UN peacekeeping plan in the months following its endorsement. ${ }^{47}$ The US and EC's recognition of the republic's independence in the midst of the conflict furthered the deepening mistrust and animosity already separating the ethnic actions, throwing another wrench into an already complicated scenario.

${ }^{44}$ The term 'ethnic cleansing' has been used to designate the practice of 'rendering an area ethnically homogeneous by using force or intimidation to remove persons or given groups from the area.' Interim Report of the Commission of Experts Established Pursuant to Security Council Resolution 780 (1992), UN SCOR, Annex 55, UN Doc. 5/25274 (10 February 1993).

${ }^{45}$ See, e.g., report of the Secretary-General pursuant to Security Counsil Resolution 760 UN SCOR, UN Doc. S/24080, para. 18 (describing the desperate situation emerging in Bosnia-Herzegovina as 'one of the worst humanitarian emergencies of our time').

${ }^{48}$ Repeatedly, the Security Council deferred settlement of the dispule in Bosnia to the EC, noting the continuing role that the EC played in achieving a peaceful solution in Yugoslavia through the Conference on Yugoslavia, commending its efforts, and demanding that all parties concerned co-operate fully with the efforts of the EC to bring about urgently a negotiated political solution respecting the principle that any change of border by force is not acceptable.' SC Res. 652, UN SCOR, 2918th mtg., 652 (1992); SC Res. 727, UN SCOR, 3028th mtg., UN Doc. S/Res/727 (1992); SC Res. 740, UN SCOR, 3049th mtg., UN Doc. S/Res/7/40 (1992); SCRes. 743, UN SCOR, 3055th, mtg., UN Doc. S/Res/743 (1992); SC.Res. 749, UN SCOR, 3066th mtg., UN Doc. SI Res/749 (1992); SC Res. 757 UNSCOR, 3082nd mtg., UN Doc. S/Res/757, (1992); SC Res. 762, UN SCOR, 3088th mtg., UN Doc. S/Res/762 (1992); SC Res. 764, UN SCOR, 3093rd mtg., UN Doc. S/Res/764 (1992).

${ }^{47}$ Referring to the Serb-Croat confilict in Resolution 762, the Council urges 'all parties and others concerned to honour their commitments to effect a complete cessation of hostilites and to implement the United Nations peacekeeping plan' (citing the Vance plan of December 1991). SC Res. 762, ibid., para. 2. In Resolution 764, the Council stressed 'once again the imperative need to find an urgent negotiated political solution for the situation in Bosnia and Herzegovina.' SC Res. 764, Ibid. 
Over a year after conflict erupted in the former Yugoslavia, the Intemational Conference on the Former Yugoslavia (London Conference), successor to the Conference on Yugoslavia, ushered in what was hoped to be a fresh chapter in the peace process-the building of a new diplomatic machinery. Secretary-General BoutrosGhali anticipated that the London Conference would 'create a new momentum', ${ }^{48}$ organised to remain in continuous session until a final settlement was reached. ${ }^{49}$ The London Conference combined an unprecedented coalition of the United Nations and the European Community 'to deal with a situation fraught with danger for inter- national peace and security. ${ }^{50} \mathrm{EC}$ envoy Lord David Owen entered the negotiating scene as Co-Chaiman of the Steering Committee of the London Conference, ${ }^{51}$ forming a joint effort with UN representative Cyrus Vance. Owen was charged with forging the EC's efforts through the Conference on Yugoslavia and heading up the activities of the United Nations in order to prepare the basis for a general settlement of the Yugoslav war. ${ }^{52}$ Vance and Owen's assignment encompassed the formidable task of reconciling the three widely divergent views of the Muslims, Croats, and Serbs on the future of BosniaHerzegovina, which were fundamental to an even-

${ }^{46}$ Steve Crawshaw \& Tony Barber. "Inside Story: Peace? What Peace?" The Independent. 30 August 1992 at 17.

${ }_{49}$ International Conference on the Former Yugosiavia, 27 August 1992, UN Doc. LC/C4 Final, reprinted in International Conference on the Former Yugoslavia: Documents Adopted at the London Conference, 31 ILM 1488, 1534 (1992). The International Conference on the Former Yugoslavia envisaged two stages: (1) the London Conference, convening 26-28 August 1992; and (2) the Geneva Process, convening 3 September 1992 , to meet in continuous session in Geneva until a settlement was reached. Ibid. While the resignation of EC Conference Chairman Lord Carrington indicated the failure of a year-long mission, the London Conference was intended to act as a tuming point in the peace process, to tackle the obstacles to a settlement of the disputes between the Croats, Bosnian-Muslims, and Serbs. See e.g. Judy Dempsey, Carrington Resigns as EC Peace Envoy to Yugoslavia, Financial Times, 26 August 1992 at 1.

${ }^{50}$ Report of the Secretary-General on the International Conference on the Former Yugoslavia, UN SCOR, UN Doc. S/24795 (19920 reprinted in 31 ILM 1549, 1558(1992) at 1552. The London Conference combined the efforts of the UN, the EC, the Conference on Security and Co-operation in Europe (CSCE), the Organisation of the Islamic Conference (OIC), and other international organisations. Ibid.

${ }^{51}$ Chris Moncrieff, "Lord Owen Sets Off on Peace Trail." Associated Press Newsfile. 30.August 1992. Lord David Owen, a former Labour cabinet minister of the United Kingdom (UK), was one of the founders and subsequent leaders of the now-defunct Social Democratic Party of the UK.

52 London Conference Report, aboven 49 at 1552. The Permanent Co-Chairmen of the London Conference are the Head of State Government of the Presidency of the European Community, British Prime Minister John Major, and the Secretary-General of the United Nations, Boutros Boutros-Ghali. Vance and Owen managed the operational work of the Conference as $\mathrm{Co}$-Chairmen of the Steering Committee, overseeing the work of six Working Groups on: (1) Bosnia- Herzegovina; (2) Humanitarian Issues; (3) Ethnic and National Communities and Minorities; (4) Succession Issues; (5) Economic lssues; and (6) Confidence and Security-Building and Verification Measures, Ibid. 
tual compromise solution of the conflict. ${ }^{53}$ Thus, Vance and Owen embarked on their mission to implement a negotiated settlement encompassing a comprehensive list of demands that seemed unrealistic in light of the past difficulties in securing a lasting agreement on the most basic principles. Widespread support of the Vance-Owen Geneva peace plan for Bosnia-Herzegovina rose from the ashes of the failed efforts of the European Community and the United Nations to effectively handle the Yugoslav crisis. As the situation spiralled out of control, the UN increasingly defended the Vance-Owen agenda of diplomacy and conciliation as the best hope for resolving the conflict. The UN thus allowed the peace process to serve as the scapegoat, hoping to shield attention away from the UN's own inept handling of the threat to international peace.

\section{International Response to the Yugosjav Crisis Through Legal Process}

Over the next several months, the situation in Bosnia-Herzegovina deteriorated rapidly with the Security Council's already shaky peacekeeping and humanitarian efforts threatened by reports of widespread violations of international humanitarian law, the Serbs' continued mass forcible expulsion and deportation of Bosnian-Muslims in the region, ${ }^{54}$ the imprisonment and abuse of civilians in deten-

${ }^{53}$ See Ibid at 1554. Although the three parties held divergent views on the future structure of BosniaHerzegovina, the co-chaimen believed that, given the intermingled population of Bosnia, there 'appear[ed] to be no viable way to create three territorially distinct States based on ethnic or confessional principles,' and thus, the establishment of a decentralised state is the only 'viable and stable solution that does not acquiesce in already accomplished ethnic cleansing.' Ibid. at 1559. A Statement of Principles emerged from the London Conference to serve as the basis of a future negotiated settlement, providing for: the cessation of fighting and the use of force by all parties; the non-recognition of advantages obtained by the use of force; respect for individual rights and fundamental freedoms as embodied in international humanitarian law; the condemnation of forcible expulsions and illegal detentions; respect for independence, sovereignty, and territorial integrity; compliance with Security Council Resolutions; the provision of humanitarian assistance; and co-operation in monitoring, peacekeeping, and arms control operations. Additionally, the Conference generated a Statement on Bosnia, setting forth the provisions necessary for a political settlement in Bosnia-Herzegovina. London Conference Documents, above n 49 at $1533,1537$.

${ }^{54}$ Secretary-General Boutros Boutros-Ghali stated:

All international observers agree that what is happening is a concerted effort by the Serbs of BosniaHerzegovina, with the acquiescence of, and at least some support from, JNA, to create 'ethnically pure' regions in the context of negotiations on the 'cantonisation' of the Republic in the EC Conference on Bosnia-Herzegovina. Ibid. para. 5 . In addition to the more than 900,000 persons displaced from Croatia, at the time of Vance's arrival on 14 April 1992, an estimated 184,000 persons had been displaced from Bosnia-Herzegovina. By April 20 of that year, this number had grown to 230,000 , and by May, over 520,000 persons had been displaced from Bosnia. Report of the Secretary-General Pursuant to Security Council Resolution 757 UN SCOR, Annex, UN Doc. S/24075 (1992). para. 15. 
tion centres, and the wanton devastation and destruction of property. ${ }^{55}$ The full extent of the atrocities had yet to unfold:

In the summer of $1992 \ldots$. the world leamed of mass forced population transfers of Muslims in convoys of cattle trucks, of organised massacres and the physical destruction of whole towns, including more than one thousand major historical, religious and cultural monuments throughout Bosnia and Croatia; of the systematic and repeated rape of as many as 20,000 Muslim women and young girls; and of the existence of over four hundred Serb-run detention centres where tens of thousands of Bosnian Muslims were being tortured and killed in a manner reminiscent of the Nazi-run concentration camps of World War II. While most of these atrocities were being committed by Serb forces, the reports clearly indicated that all parties to the conflict had committed abuses against other ethnic groups. $^{56}$
In response to the deteriorating human rights situation in the former Yugoslavia, the UN Commission on Human Rights was called into its first ever special session, during which it adopted resolution 1992/S-1/1 on 14 August 1992, requesting the Chairman of the Commission to appoint a special rapporteur 'to investigate first hand the human rights situation in the territory of the former Yugoslavia, in particular within Bosnia and Herzegovina'. ${ }^{57}$ The first report of Special Rapporteur Mazowiecki to the Commission on Human Rights concerned, inter-alia, the policy of ethnic cleansing and other serious human rights violations committed in the territory of the former Yugoslavia. The report stated that " $t$ the need to prosecute those responsible for mass and flagrant human rights violations and for breaches of international humanitarian law and to deter future violators requires the systematic collection of documentation on such crimes and of personal data concerning those responsible. ${ }^{.58}$ The Special Rapporteur then recommended that '[a] commission should be created to as-

${ }^{55}$ See, e.g., SC Res. 752, aboven 42 (expansion of UNPROFOR mandate); SC Res. 757, UN SCOR, 3082th mtg., UN Doc. S/Res/760 (1992) (general sanctions imposed); SC Res. 758, UN SCOR, 3083th mtg., UNDoc. (1992); SC Res. 760, UN SCOR, 3086th mtg., UN Doc. S/Res/760 (1992); SC Res. 761, UN SCOR, 3087 th mtg., UN Doc. S/Res/761 (1992) (demand that all parties and others concerned co-operate fully with UNPROFOR and intemational humanitarian agencies and organisations and take all necessary steps to ensure the safety of their personnel); SC Res. 762, UN SCOR, 3088th mtg., para. 2, UN Doc. S/Res $/ 762$ (1992) (expanding UNPROFOR's mandate); SC Res. 764, UN SCOR, 3093rd mtg., UN Doc. S/Res/764 (1992) (authorising.UNPROFOR to protect humanitarian assistance); SC Res. 771, UN SCOR, 3106th mitg., UN Doc. S/Res/771 (1992).

${ }^{56}$ Morris \& Scharf, above $n 5$ at 22.

${ }^{57}$ See Report on the Situation of Human Rights in the Territory of the former Yugoslavia submitted by Mr. Tadeusz Mazowiecki, Special Rapporteur of the Commission on Human Rights, pursuant to paragraph 14 of Commission resolution 1992/S-1/1 of 14 August 1992, E/CN.4/1992/S-1/9, 28 August 1992.

${ }^{58} /$ bid at para. 69. 
sess and further:investigate specific cases in which prósecution may' be warranted: i'This information should include data already collected by various entities within the United Nations system, by other intergovernmental organisations and by nongovemmental organisations. ${ }^{59}$

Subsequently, a number of reports called for criminal investigation of war crimes and serious violations of humanitarian law as well as the timely collection of information and evidence to support such investigations. ${ }^{60}$ Various Governments, international organisations and non-governmental organisations also urged international prosecutions to be carried out but this calls met with a lukewarm attitude from a Security Council reluctant to face the Herculean task that international penal process would entail and hesitant to antagonise the efforts at political settlement by the $E C$ and UN. The Security Council was however keen on deflecting international criticism and on 13 August 1992, adopted Resolution 771 , requiring Member States to submit reports on viola- tions of humanitarian law perpetrated in the territory of the former Yugoslavia. Finally in response to sustained internal and external criticism, action by the UN came in the form of a 'war crimes commission,' established to better assimilate the massive information and evidence of alleged war crimes being turned over to the UN. On 6 October 1992, the Security Council adopted resolution $780^{61}$ which:

Request[ed] the Secretary-General to establish, as a matter of urgency, an impartial Commission of Experts to examine and analyse the information submitted pursuant to resolution 771 (1992) and the present resolution, together with such further information as the Commission of Experts may obtain through its own investigation or efforts, of other persons or bodies pursuant to resolution 771 (1992), with a view to providing the Secretary-General with its conclusions on the evidence of grave breaches of the Geneva Conventions and other violations of international humanitarian law committed in the territory of the former Yugoslavia.

${ }^{59} / \mathrm{bid}$ at para. 70.

${ }^{60}$ See e.g. E/CN.4/1992/S-1/10 of 27 October 1992 at para 18 as well as Annex 11 (Statement by Dr. Clyde Snow). See also Report of the Special Rapporteur(transmitted by the Secretary-General to the Security Council and General Assembly) A477/666; S/24809 of 17 Nov. 1992, para. 140, where Mr. Mazowiecki stated: 'There is growing evidence that war crimes have been Committed. Further investigation is needed to determine the extent of such acts and the identity of those responsible, with a view to their prosecution by an international tribunal, if appropriate'. See further the later reports of the Special Rapporteur for more details on the human rights situation in the former Yugoslavia: E/CN.4/1993/50 of 10 February 1993; E/CN.4/1994/3 of 5 May 1993; E/CN.4/1994/ 4 of 19 May 1993; E/CN.4/1994/6 of 26 August 1993; E/CN.4/1994/8 of 6 September 1993; E/CN.4/1994/47 of 17 November 1993; E/CNA/1994/1 10 of 21 February 1994; E/CN.4/1995/4 of 10 June 1994; E/CN.4/1995/ 10 of 4 August 1994; A/49/641 -S/1 994/1252 of 4 November 1994; E/CN.4/1995/54 of 13 December 1995; El CN.4/1995/57 of 9 January 1995; E/CN.4/1996/3 of 21 April 1995; and E/CN.4/1996/6 of 5 July 1995 . On 27 July 1995, Mr. Mazowiecki informed the Commission of his decision to resign his mandate. The responsibilities of the Special Rapporteur on the former Yugoslavia were taken up by Ms. Elisabeth Rehn of Finland as of September 1995.

${ }^{81}$ See SC Res 780 (1992) adopted by the Security Council at its 3119th meeting, 6 October 1992. Reprinted in 31 ILM (1992) 1476. 
In October 1992, the Secretary-General constituted a five-member independent and impartial Commission of Experts to determine whether there were grave breaches of the 1949 Geneva Conventions. ${ }^{62}$ The Commission collected information from various sources, carried out a number of investigations; and submitted three reports to the Secretary-General on. serious violations of intemational humanitarian lawin the territory of former Yugoslavia, referring to widespread patterns of wilful killing, ethnic cleansing, mass killings, torture, rape, pillage and destruction of civilian property, destruction of cultural and religious property and aritrary arrests. ${ }^{63}$

With international pressure mounting over the gross and systematic violations of human rights, captured vividly in various reports, print and electronic media, on 22 February 1993, the Security Council unanimously adopted Resolution 808 , which underlined the Council's intention to create an international tribunal to prosecute individuals responsible for serious violations of international humanitarian law committed in the territory of former Yugoslavia since 1991' and requested the Secretary-General to report on all aspects of the matter and to make specific proposals on the resolution's implementation..$^{64}$ Not all of the Security. Council's Permanent Members supported the initiative for a tribunal, which was seen as potentially disruptive of negotiations for a political settlement of the conflict. Some Security Council mem- bers, as well as other Member States, felt that such a judicial organ should be established by the General Assembly or by a multilateral treaty. Other members urged that this was an opportunity to establish a permanent international criminal court, but the political advantages of controlling ad hoc institutions by the Security Council prevailed.

Arguably the peace settlement negotiations by Vance and Owen were not helped by the formation of the 'war crimes commission'. The political climate and the intensity of the conflict at that time created a situation in which the pursuit of a political settlement was deemed a priority. The alleged 'criminals' were the very same leaders of the Yugoslav factions that Vance and Owen were assigned to pressure and cajole into a political settlement over the future of Bosnia-Herzegovina. Certainly, the last thing that Vance and Owen needed was a war cimes that would demonstrate the criminality of Serbian leaders, including Milosevic, and the victimisation of the Bosnians. If that happened, world public opinion would clamour for accountability for the atrocities. Milosevic and other Serbian leaders would not, under these circumstances, agree to a negotiated settlement when they were the targets of the war crimes commission's investigation. Owen thought that equal moral blameworthiness was needed to achieve a climate that would convince the Bosnians to accept whatever the Serbians dictated, and to avoid focusing on the prospect of the prosecution of Serbian leaders.

${ }^{62}$ See Report of the Secretary-General on the Establishment of the Commission of Experts Pursuant to Paragraph 2 of Security Council Resolution 780 (1992), UN Doc. S/24657 (1992).

${ }^{33}$ See UN Doc. S/25274 of 9 February 1993.

${ }^{64}$ See SC Res. 808, UNSCOR, 3175th mtg., UN Doc/803 (1993). 
The pursuit of justice was a response to international humanitarian concerns and to the terrible atrocities of the war that the media brought so vividly to the attention of world public opinion. But, because the major powers did not want to intervene militarily, the UN and EC mediators had neither a stick nor a carrot to induce cessation of hostilities. The establishment of an international investigative body with the broadest possible mandate since Nuremberg was just the sort of stick that the UN and EC mediators needed to pressurise the Serbian leadership. However, political settlement negotiations could not be conducted while the prospects of criminal investigation and eventual prosecution existed. In the face of this dilemma, the choice made was to favour politics over justice. As a result, the Commission never received adequatë funding from the $U N$ to conduct its field investigations. The limited resources provided by the UN only covered the bare minimum of administration costs for a short period of time. Moreover, the UN frequently placed bureaucratic and financial hurdles in the Commission's way. Consequently, the Commission resorted to extemal funding sources and accepted the aid of volunteers and personnel contributed by certain gov- emments. ${ }^{65}$

As the Commission's work and database work grew and became substantial enough to evidence pattems of criminality that could not have occured without design and senior political and military leadership involvement, the Commission's work became threatening to the political process ${ }^{66}$ Consequently, it became politically necessary to terminate the work of the Commission while attempting to avoid the negative consequences of such a direct action. The Commission of Experts was arbitrarily teminated on 30 April 1993 by a decision of the United Nations Office of Legal Affairs (OLA) contrary to the Security Council's mandate in Resolution 827 , which requested that the Commission of Experts continue its work pending the appointment of a prosecutor for the Tribunal, however the prosecutor did not take office until $15 \mathrm{Au}$ gust 1994, almost eight months after the OLA told the Commission of Experts to terminate activities. By employing bureaucratic measures, an obstruction of justice was carried out quietly. An administrative decision was taken-probably at the behest, but certainly with the support of, some of the Permanent Members-leaving no legal trace of the deed. ${ }^{67}$

\footnotetext{
${ }^{65} \mathrm{M}$ Cherif Bassiouni \& Peter Manikas, The Law of the International Criminal Tribunal For The Former Yugosiavia(1996), p. 40.

${ }^{60}$ While press reports charging responsibility for 'ethnic cleansing, ' 'systematic rape,' and other systematic violations of international humanitarian law could be ignored, evidence substantiating these allegations was a real threat.

${ }^{67}$ The reasons for this action were not explained and the Security Council did not take a position on the termination of the Commission of experts. Nevertheless, the Secretary-General, in a 1995 report to the Commission of Human Rights, incorrectly stated that the Commission of Experts 'concluded its work by 30 April 1994 in accordance with the decision under the terms of the SC resolution 827 (1993).' See Situation on Human Rights in Bosnia and Herzegovina: Report of the Secretary-General, UN ESCOR, 51st Sess., 15, UN Doc. E/CN.4/ $1995 / 62$ (9 February 1995). The year-long delay in the appointment of Richard Goldstone as Prosecutor is evidence of the politicisation of the Tribunal. The Secretary-General presented his first nomination for the Prosecutor to the Security Council in August 1993. In the same month, the UK requested the Security Council to
} 
On 3 May 1993, the Secretary-General duly submitted his report to the Security Council as requested: ${ }^{68}$ The report explains the legal basis for the tribunal's establishment, its competence and organisation, investigation and pretrial proceedings, trial and post-trial proceedings (including those relating to the rights of the accused, witness protection, judgment and penalties, appeal, review and the enforcement of sentences), and makes provision for co-operation and judicial assistance of States with the Tribunal. The Statute of the International Criminal Tribunal for the Former Yugoslavia, as proposed by the Committee of Experts to the Secretary-General, formed the appendix to the Secretary-General's report.

The Security Council was presented with a difficult choice. It could either rigidly uphold the sanctity öf State sovereignty, even at the risk of allowing homific acts of war to go untried and unpunished, or it could undermine State sovereignty in a move that clearly overrode the wishes of the States most closely involved by creating an international criminal tribunal-one that would demand the extradition of those States' nationals for'public trial, make incursions into their demarcated territories for the exact purpose of collecting evidence by which to pros- ecute their nationals, exhume their mass grave sites, and, not unimportantly, deepen a sense of subjugation in States already angered by a perceived prejudice against them. The Security Council opted to invoke Chapter VII. On 25 May 1993, the Security Council adopted Resofution 827 and unanimously approved the report of the Secretary-General, deciding:

...to establish an intermational tribunal for the sole purpose of prosecuting persons responsible for serious violations of international humanitarian law committed in the territory of former Yugoslavia between 1 January 1991 and a date to be determined by the Security Council upon the restoration of peace and to this end to adopt the statute of the International Tribunal annexed to the report of the Secretary-General. ${ }^{69}$

For such a striking move as the creation of an international criminal tribunal established under the auspices of the United Nations, there was surprisingly little dissent within the larger international community. Although several countries offered draft statutes that differed in jurisdictional scope and other powers from the final statute, ${ }^{70}$ only one country actually denied

appoint the Prosecutor by consensus, thereby effectively ensuring that a candidate would not be approved if one of the major powers opposed the nomination. However the Security Council's final selection of Richard Goldstone of South Africa as Prosecutor did not occur until mid-July 1994. See Bassiouni and Manikas, above n 65 at 210-12.

${ }^{68}$ See Report of the Secretary-General Pursuant to paragraph 2 of Security Council Resolution 808 (1993), UN Doc. S/25704 of 3 May 1993.

${ }^{69} \mathrm{~S} / 25704$ of 3 May 1993 \& Add. 1 of 17 May 1993.

${ }^{70}$ France, Italy, and Sweden (on behalf of the CSCE) made proposals. Formal suggestions (in contrast with the unpublished informal submissions of other States) were made by Brazil (UN Doc. A/47/922-S/25540 (1993)); Canada (UN Doc. S/25594 (1993)); Egypt, Iran, Malaysia, Pakistan, Saudi Arabia, Senegal, and 
the power of the Security Council to establish a tribunal at all. Not surprisingly, this was the Federal Republic of Yugoslavia, which argued that its State sovereignty would be unacceptably violated by the establishment of a tribunal that held the prejudicial goal of prosecuting Serbs. ${ }^{71}$ Yugoslavia voiced its objections in a letter addressed to the Secretary-General stating that while 'Yugoslavia considers that all perpetrators of war crimes committed in the territory of the former Yugoslavia should be prosecuted and punished, ${ }^{72}$ it stated that this was the proper mandate for national, as opposed to intemational, laws and tribunals. The intemational community was not deaf to the Republic's arguments, for several countries and organisations submitted draft statutes that differed in the extent of the jurisdiction granted to the Tribunal. Even the CSCE, as Yugoslavia rightly pointed out, had concems about respecting the internal sovereignty of the
States involved in the conflict. ${ }^{73}$ In recognition of this concem over respect for State sovereignty, some States had suggested that the General Assembly play a role in the creation of the Tribunal, such as participating in drafting or reviewing its statute. ${ }^{74}$

\section{The Dayton Accord: The Balkan Peace Agreement and the Failure of NATO to Act as a Tool for Enforcing Interna- tional Justice}

Despite the tremendous efforts of Vance and Owen, the success of the political settlement process over Bosnia-Herzegovina remained to be realised, in large part due to the fact that the UN's hesitant and often equivocal actions made an eventual peaceful settlement of the Bosnian conflict dubious. Tracing the UN's haphazard response to the Yugoslav cri-

Turkey, on behalf of the members of the Organization of the Islamic Conference (OIC) and as members of the OIC Contact Group on Bosnia and Herzegovina (UN Doc. A/47/920-S25512 (1993)); Mexico (UN Doc. S/25417 (1993)); Netherlands (UN Doc. S/25716 (1993)); Russian Federation (UN Doc. S/25537 (1993)); Slovenia (UN Doc. S/25652 (1993)); and the United States (UN Doc. S/25575 (1993)). See Morris \& Scharf, above $n 5$ at 32 n. 120 .

${ }^{71}$ See Letter Dated 19 May 1993 From the Charge D'Affaires A.I. of the Permanent Mission of Yugoslavia (Serbia and Montenegro) to the United Nations Addressed to the Secretary-General, UN Doc. A448/170-SI 25801 (1993) (Yugoslav letter), paras. 6 \& 10.

${ }^{72} /$ bid. at para. 3.

${ }^{73}$ The CSCE Rapporteurs felt that the jurisdiction of an international tribunal should be limited to the two States-Bosnia:Herzegovina and Croatia- thathad agreed to the establishment of such a tribunal. See generally Proposal for an International War Crimes Tribunal for the former Yugoslavia, UN Doc. S/25307 (1993) (Rapporteurs Corell, Turk, and Thune under the CSCE Moscow Human Dimension Mechanism to Bosnia and Herzegovina and Croatia).

${ }^{74}$ For example, see the submissions of Brazil, France, and Mexico contained in UN Docs. A/47/922-S/ $25540, S / 25266$, and $S / 25417$, respectively. The roles envisaged for the General Assembly did not include the actual adoption of the statute or the establishment of the tribunal. As noted in the French proposal, the General Assembly does not have the authority to adoptmandatory resolutions. See Morris \& Scharf, above $n 6$ at $40, n$ 144. 
sis, marked more by "improvisation and ingenuity than by steadfast determination and willingness to make or risk some sacrifices, ${ }^{75}$ it is clear that the UN did too little, too late, to foster the Vance-Owen agenda, thus provoking the international community to consider ways to impose peace. With the UN and $E C$ attempts at political settlement over two years in shambles, the US stepped into the fray. Despite the formation of the ICTFY, it was still essential to reach a political settlement to end the war in Bosnia and put an end to the brutal atrocities. The Dayton Peace Agreement was signed as a means to bring to an end the war in Bosnia and Herzegovina. ${ }^{76}$

The Dayton Agreement was negotiated in a purposefully created hothouse environment at the secluded Wright Patterson Air Force Base in Dayton, Ohio. ${ }^{n}$ It was signed by the negotiating parties and a group of guarantor States, who were prepared to endorse and materially support a peace settlement for the Bosnian War, in Paris, on 14 December 1995. The Dayton Peace Agreement (DPA) came after numerous failed diplomatic attempts by Western mediators to secure an end to war. ${ }^{78}$ The DPA is a complex package of inter-related texts augmented by Security Council resolutions that establish the international forces and organs which support the Agreement. ${ }^{79}$

In the Western guarantor States the agreement was widely heralded as a triumph of diplomacy over chaos, a reasoned agreement over crude warfare, and a multilateral agreement that forced confirmation of the legal existence and viability of the Bosnian State by all parties to the conflict. Despite the undeniable accomplishment of ending mass fratricidal violence on Bosnian territory, the Agreement is a

${ }^{75}$ Paul Szasz, Introductory Note, 'Documents Regarding the Situation in the Former Yugoslavia' 31 ILM $1421(1992)$.

${ }^{76}$ The Dayton Peace Agreement, below n 80 was signed in Paris on 14 December 1995 and was witnessed by the Presidents or Prime Ministers of the United States, the Russian Federation, the Federal Republic of Germany, the United Kingdom, France, and by the European Union special negotiator. For useful accounts of the background to the conflict, see generally Mark Almond, Europe's Backyard War: The War in the Balkans (1994); Noel Malcolm, Bosnia: A Short History(1994); Branka Magas, The Destruction of Yugosiavia: Tracing the Break-Up. 1980-92.

"See generally, Dick A. Leurdijk. "The Dayton Agreement: A Tremendous Gamble" (December 1995January 1996). 3 International Peacekeeping 2.

' 78 These included the EC Conference on Peace in Yugoslavia ('Carrington'); the UN/EC co-sponsored International Conference on the Former Yugoslavia, August 26-27, 1992; and the Vance-Owen Plan (the Principle stages of the Vance/Owen Plan are set out in UN Documents S/24795, Annex VII, 31 ILM 1584 (1992)). It should be noted that the argumentmay be made that the inclusion of Russia in the Contact Group, facilitated largely by the United States, was a mechanism to avoid movement on 'hard' issues. On one view the inclusion of Russia appears to create a varied international presence and consensus on Bosnia, it also creates the indefinite inclusion of intemal competing agendas in the management of the conflict.

${ }^{79}$ See UN Security Council Resolution 1021 of 22 November 1995, 35 ILM 257 (1996); UN Security Council Resolution 1022 of November 22, 1995, 35ILM 259 (1996); UN Security Council Resolution 1026 of 30 November 1995, 35 LLM 251 (1996). 
paradox of both substance and implementation. The DPA confirms the existence of the State yet contains the ingredients that divide it into separate political and legal entities. The treaty pays homage to the language of self-reliance while ensuring that a long-term international presence remains a necessary êtement for the survival of the state. The Dayton Agreement fortifies the tripartite division of nation, community and individual in the new Bosnia where ethnic identity is all, and the body politic is a fractured soul.

The Dayton Accords, in which several of the annexed or related instruments to the General Framework Agreement for Peace in Bosnia and Herzegovina (GFA) were initialled by representatives of the principal States to the conflict in Bosnia-the Republic of Bosnia and Herzegovina, the Repüblic of Croatia, and the Federal Republic of Yugoslavia (Serbia and Montenegro)-and twelve instruments annexed to the GFA were initialled or otherwise endorsed on behalf of the Federation of Bosnia and Herzegovina and the Republika Srpska. ${ }^{80}$ 'In the Dayton Accords, the Republics of Bosnia-Herzegovina, Croatia, and the Fedèral Republic of Yugoslavia (representing the Republika Srpska) agreed to 'wel- come and endorse the arrangements that were made concerning the establishment of an arbitration tribunal ... [and] fully respect and promote fulfilment of the commitments made therein. ${ }^{181}$

The day the Dayton Accords were signed by the parties in Paris, the President and the Prosecutor of the Yugoslavia Tribunal issued a joint statement. The statement underscored 'the authority of IFOR to arrest indicted war criminals' and concluded that 'this Agreement promises that those who have committed crimes which threaten international peace and security-genocide, crimes against humanity and war crimes-will be brought to justice.' But this optimistic public assessment of the role of IFOR in apprehending indicted war criminals was not shared behind the scenes by many of the Tribunal's top officials.

The Dayton Accords contained several provisions requiring the parties to co-operate with the ICTFY. Article IX of the General Framework Agreement and Article XIII (4) of the Agreement on Human Rights required the parties thereto (Bosnia, Croatia, and the FRY) to cooperate fully with and give unrestricted access to the ICTFY, and this requirement was extended to the Republika Srpska by Article IV of the Agreement on Civilian Implementation.

${ }^{80}$ Annexed and related instruments of the General Framework Agreement for Peace in Bosnia and Herzegovina (GFA) were initialled by representatives of the Republic of Bosnia and Herzegovina, the Republic of Croatia, and the Federal Republic of Yugoslavia (Serbia and Montenegro, also acting on behalf of the 'rump republic,' Republika Srpska). The GFA and several instruments appurtenant to it were formally signed in Paris on 14 December 1995 and thereby immediately came into force. See Paul C. Szasz." Current Development: The Protection of Human Rights Through the Dayton/Paris Peace Agreement on Bosnia." (1996) 90 American Joumal of Intemational Law 301. p. 301. The Dayton/Paris Peace Agreement is reproduced in UNDoc. A50/ $790-\mathrm{S} / 1995 / 999$ in the form initialled on 21 November 1995 in Dayton and appears in 35 ILM 89 (1996) in the form signed on 14 December 1995 in Paris. The two differ solely in the correction of some minor errors that appeared in the earljer text. See /bid at $301 \mathrm{n} 2$.

${ }^{8 f}$ Dayton Peace Agreement, Ibjd., article VI. 
Much was made of this language, and the Tribunal called upon the Security Council to insist that the co-operation of the States is owed. Nonetheless, it is well known that in practice the parties' commitment to 'welcom[ing]' ${ }^{82}$ or 'cooperat[ing] ... with' ${ }^{\text {B3 }}$ the Tribunal fell short of this pledge. The Federal Republic of Yugoslavia, initially totally refused to recognise the jurisdiction of the Tribunal and it was not until five years later (in 2000) that the Republic softened (not rejected) its stance. ${ }^{84}$

The former Yugoslav republics were not alone in their initial hostility and later extreme reluctance towards co-operating with the ICTFY. Even after the ICTFY was established, few prosecutions occurred initially, because NATO forces were reluctant to apprehend indicted criminals for fear of retaliation. Most shocking was the initial refusal of NATO to arrest war crimes suspects following the Americanbrokered Dayton Accords and the deployment of 60,000 troops in Bosnia. ${ }^{85}$ Perhaps the reason lies in the American reliance on Milosevic, the then Serbian President many viewed as the architect of the genocidal war, to broker the agreement. ${ }^{86}$ In any event, the Accords largely ratified the gains of the Serbs, leaving the Bosnian Muslims with only fifty-one percent of Bosnia-Herzegovina, a Muslim-Croat federation; the rest became Republika Srpska, a separate and autonomous Serb republic, and a haven for Karadzic and Mladic, two of the most senior Serbs indicted by the ICTFY. ${ }^{87}$

Despite the creation of the ICTFY and the Western countries' repeated promises to support the Tribunal's mandate. It is no secret that the actual implementation of the Dayton Accord was initially miserable. There were two initial successes: the military confrontations and the slaughters of civilians came to a prompt halt; and, a little later, NATO troops managed to nudge the armies of the several parties to the boundaries prescribed by the Dayton Accord.8 The failures were many but most significantly, the principal and many other war criminals remained at large, for the most part in plain sight; in spite of explicit prohibitions in the Constitution, many of these criminals were officially or

\section{${ }^{82} \mathrm{lbid}$. \\ ${ }^{83}$ Ibid., Article IX.}

${ }^{84}$ In addition to the legal arguments it framed in its letter to the Secretary-General of 19 May 1993, in which the Permanent Mission of Yugoslavia challenged the authority of the Security Council to establish a tribunal, officials of the Federal Republic of Yugoslavia declared that they did not recognise the competence of the Tribunal.' Yugoslav letter, above n 71. See also Bassiouni \& Manikas, above $n 65$ at 238.

- ${ }^{85}$ E. Sciolino, "Accord Reached to End the War in Bosnia; Clinton Pledges US Troops to Keep Peace," New York Times, 22 November 1995; at A1. The Dayton Accords were initialled on 21 November 1995, by the presidents of Bosnia-Herzegovina, Croatia, and Serbia in Dayton Ohio, ending the four-year war in the former Yugoslavia.

8s'Dissembling in Serbia. Asian Wall Street Joumal. 10 February 1997 at 12, available in Westlaw, inthews.

${ }^{87}$ Physicians for Human Rights, Medicine Under Siege in Yugoslavia: 1991-1995 (1996) 32.

${ }^{88}$ Inter-Entity Boundary, Annex 2 to the General Framework Agreement For Peace in Bosnia and Herzegovina, 14 December 1995, 35 ILM 111(1996). 
effectively running their respective fiefdoms contrary to the provisions of the Dayton accords. ${ }^{89}$ NATO through its policy of 'monitor, but don't touch' largely failed to use force to implement international criminal justice-by apprehending indicted war criminals in its area of operations in Bosnia despite its massive military presence. To justify its inaction, the NATO commanders initially claimed that NATO's mandate in Bosnia did not permit use of force in aid of international criminal justice except under extremely limited circumstances (i.e., when indicted war criminals are 'encountered in the course of its duties and if the tactical situation permits'). ${ }^{90}$

Initially the ICTFY remained a symbolic gesture without the wherewithai to discharge its mission. The US feared that going after suspects would upset the Dayton Accords. ${ }^{91}$ In any event, both the US and NATO forces initially carried out a policy of appeasement towards
-

indicted war criminals. ${ }^{92}$ NATO forces were keen in discharging the initial official policy of 'monitor, don't touch' in relation to the war criminals but subsequently under intemational pressure and condemnation resorted to limited case by case arrests ${ }^{93}$ arguably to deflect international criticism and condemnation of NATOs passivity and aloofness in assisting the ICTFY inspite of its formidable military resources. Clearly, in its early days, the Dayton Accord was not being carried out in good faith by anyone, including the BH and the GFA Parties on the one hand, and the Sponsoring Powers on the other. ${ }^{94}$

\section{Conclusion}

Charged with the maintenance of international peace and security, the United Nations fell short of fulfilling this mandate when it virtually ignored the Yugoslav crisis until it had spi-

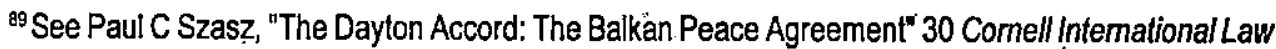
Journal 759, p. 765-766

${ }^{90}$ See Press Briefing by National Security Adviser Berger on Bosnia, US Newswire, 10 July. Later, NATO forces were used to apprehend a handful of low and mid-level indictees, while indicted Bosnian Serb leaders Radovan Karadzic and Ratko Mladic, and Serb President Slobodan Milosevic, were given de facto impunity.

${ }^{91}$ Dissembling in Serbia, above $n 86$.

92"War-Crimes Hypocrisy." Washington Post. 2 February 1997, at C6 (attacking American policy of appeasement of war crimes suspects, reconfirmed when Secretary of State Albright met with Louise Arbour, the new ICTFY Prosecutor). Washington Post editorial concludes war crime suspects 'have not been arrested because US troops have chosen not to arrest them-because ultimately, President Clinton has failed to order their arrests." See also "Discussions, But No Plans Yet on Catching War Criminals: Pentagon, "Agence France Presse. 11 February 1997, available in Lexis, News Library, CURNWS File.

${ }^{93}$ Michael Scharf, "The Tools For Enforcing International Criminal Justice In The New Millennium: Lessons FromTheYugoslaviaTribunal." 20009 De Paul Law Review 925, 956-964.

${ }^{84}$ With the election of Tony Blair as British Prime Minister, the United Kingdom began to press NATO for a more forceful policy on arresting indicted war criminals. Surprisingly, it was the United Nations peacekeeping force in Croatia, and not the NATO force, which made the first arrest. In June 1997, an agent of the Tribunal's Office of the Prosecutor lured indicted war criminal Slavko Dokmanovic out of Serbia and into Eastern Slavonia (Croatia), where he was apprehended by UN peacekeeping forces, and delivered to the Yugoslavia Tribunal. 
ralled out of control. Once involved, the Council relied on the parties to the Yugoslav crisis to abide by its demands to cease fighting, withdraw, and adhere to the on-again, off-again cease-fires, ignoring the underlying realities of the crisis. Ethnic factions living side by side in Yugoslavia could not answer to the rule of law, when their sacred homeland was threatened, their brothers shot, and their sisters and mothers raped. The Council's demands and pleas, coming amidst the virtual dissolution of Yugoslavia, fell on deaf ears. If the UN had entered the scene much earlier, with a peacekeeping force in place before the war was in full force, negotiations over the future of the breakaway republics might have been more successful. instead, the burden falling on Vance and Owen, to negotiate a settlement over BosniaHerzegövina, had become 'a pathetic catch-up game, in which political and territorial concessions chase the victories achieved on the ground through the ruthless use of force. ${ }^{195}$

By 1993, bureaucratic hurdles, lack of resources, non-disclosure of evidence, and other more subtle means were used to avoid impede and/or avoid the likelihood of intemational prosecutions. Thus, the Commission of Experts on the former Yugoslavia was not adequately funded for investigations, and when it accumulated evidence perceived as dangerous to the political peace process, it was arbitrarily terminated. The more fundamental decision for the States of the intemational community, however, was whether to make the concessions necessary to create an effective intemational mechanism against the background of States insisting upon preserving the totality of their sovereign prerogatives, if such a view had held sway, no effective international criminal tribunal could have been created.

It is apparent that initially, the international community failed to provide the Tribunal with the requisite support to fuifil its mandate, despite a clear legal obligation to do so. Thus, it should be equally clear that the 'success' of the Tribunal, defined by the number of suspects it actually brings to trial, was seemingly beyond the Tribunal's power to achieve. Unlike national courts, the Tribunal does not have its own police force. It is, in the words of the Tribunal's first president, 'like an armless and legless giant which needs artificial limbs to act and move. These limbs are the State authorities ... the national prosecutors, judges and police officers. If State authorities fail to carry out their responsibilities, the giant is paralysed [sic], no matter how determined its efforts. ${ }^{96}$ The paralysis of the Tribunal quickly dissipated once States were galvanised into action with the spectre an unsuccessful tribunal that was largely, if not solely reliant on State co-operation.

It can be argued that by increasing awareness the ICTFY has contributed to the global respect of human rights through its indictments and trials. It is possible that the creation of a global human rights culture can be achieved by

${ }^{95}$ Brzezinski, above $\mathrm{n} 29$.

${ }^{\infty}$ Statement of Antonio Cassese, President of the International Criminal Tribunal for the Former Yugoslavia, to the Parliamentary Assembly of the Council of Europe, Dayton Four Months On: The Parties' Co-operation with the intemational Criminal Tribunal for the Former Yugoslavia (ICTFY) under the Dayton Peace Agreement (25 April 1996). 
trying those who are responsible for shocking crimes. ${ }^{97}$ The creation of this ad hoc international tribunal is one of the most recent achievement of the human rights movement, ${ }^{98}$ but this court was stitched together with many other institutions and mechanisms to form a human rights quilt with no perceivable design..$^{99}$ it seems that the individual patches were designed without a' full understanding of the existence of other patches, let alone full consideration of how they complement each other. Thus one of the major flaws is that the ICTFY has not spectacularly translated its institutional achievement into a positive social change creating a greater respect for human rights.

\section{References}

Age Eknes. 'The United Nations' Predicament in the Former Yugoslavia' in Thomas G Weiss (ed). The United Nations and Civil Wars. (1995).

Amy Lou King. "Bosnia-Herzegvina-VanceOwen Agenda for A Peaceful Settlement: Did the UN Do Too Little, Too Late, To Support This Endeavour?"
(1993) 23 Georgia Journal of Intemational and Comparative Law.

Bassiouni, M Cherif \& Peter Manikas. The Law of the International Criminal Tribunal For The Former Yugoslavia (1996) 40.

Brzezinski, Zbigniew. "Bombs and Blather: The Strategy Deficit; Can Clinton Find America's Missing Foreign Policy?" Washington Post. 17 January 1993.

Clark, Andrew. 'Yugoslavia: Fragile Cease-fire Holds in Croatia.' Australian Financial Review. 10 October 1991.

Simpson, Gerry. 'Didactic and Dissident Stories in War Crimes Trials.' 60 Alberta Law Review 801, (discussing the trials of Eichmann, Demanjunk, Barbie, Polyukhovic, Preibke, Touvier and others).

Chapter VII allows the United Nations to use military force and act in areas otherwise reserved to the domestic jurisdiction of States. United Nations operations in Iraq, Somalia, and Haiti were all authorised under Chapter VII. See SC Res. 678, UN SCOR, 45th Sess., Res.

\footnotetext{
${ }^{87}$ 'Matthew A. Ritter, "Human Rights": Would You Recognise One If You Saw One? A Philosophical Hearing of International Rights Talk' (1997) 27 Califomia Westem International Law Joumal 265, 266). See also Jack Donnelly, Intemational Human Rights (1993); Jack Donnelly, ' international Human Rights: A Regime Analysis' (1986) 40 Intemational Organisation 599 (both stating that the UN will not allow human rights institutions to be strong because it is not in the interest of member states).

${ }^{98}$ See, e.g., Peter Rosenblum, 'Save the Tribunals; Salvage the Movement, AResponse to Makau Mutua', 11 Temple Intemational and Comparative Law Joumal 189 (1997).

${ }^{99}$ UN Secretary-General Boutros Boutros-Ghali, in his address to the eleven judges of the ICTFY, stated: ' $T$ ]he building of an intemational society govemed by law is a slow, modest, chaotic and uncertain business.' UN Doc. SG/SM/50207 (21 January 1994). For an overview of the UN human rights system, see Philip Alston (ed.) The United Nations and Human Rights: A Critical Appraisal (1992). For NGOs and human rights, see Henry Steiner, Diverse Partners: Non-Governmental Organisations in the Human Rights Movement (1991).
} 
Jackson Nyamuya Maogoto. Revisiting the Balkan Crisis ...

\& Dec., at 27, UN Doc. S/INF/46 (1990); SC Res. 794, UN SCOR, 47th Sess., Res. \& Dec., at 63, UN Doc. S/INF/48 (1992); SC Res 841, UN SCOR, 48th Sess., Res. \& Dec., at 119, UN Doc. SI INF/49 (1993).

Crawshaw, Steve \& Tony Barber."'Inside Story: Peace? What Peace?" The Independent, 30 August 1992.

'Dissembling in Serbia, Asian Wall Street Journal, 10 February 1997 at 12, available in Westlaw, Intlnews.

Dick A. Leurdijk. "The Dayton Agreement: A Tremendous Gamble" (December 1995-January 1996). 3 International Peacekeeping.

Doder; Dusko \& Louise Branson. Milosevic: Potrait of a Dictator (1999) 27. See also Roger Thurow. 'Tito's Legacy: Political Drifting, An Economy in Chaos Prevail in Yugoslavia; Question is Whether Nation Will Turn More to Soviets Out of Economic Need; Sharpening Ethnic Rivalries.' Wall Street Journal. May 1986, available in 1986 WL-WSJ 258991.

E. Sciolino. 'Accord Reached to End the War in Bosnia; Clinton Pledges US Troops to Keep Peace', NewYork Times, 22 November 1995

Eyal, Jonathan. "United Nations: Blue Flag of Inconvenience-Former Yugoslavia." Guardian. 29 January 1993.

E/CN.4/1992/S-1/10 of 27 October 1992 at para 18 as well as Annex 11 (Statement by Dr. Clyde Snow). See also Report of the
Special Rapporteur (transmitted by the Secretary-General to the Security Council and General Assembly) A/47/666; SI 24809 of 17 Nov. 1992, para. 140, where Mr. Mazowiecki stated: 'There is growing evidence that war crimes have been Committed. Further investigation is needed to determine the extent of such acts and the identity of those responsible, with a'view to their prosecution by an international tribunal, if appropriate'. See further the later reports of the Special Rapporteur for more details on the human rights situation in the former Yugoslavia: E/CN.4/1993/50 of 10 February 1993; E/CN.4/1994/3 of 5 May 1993; E/CN.4/1994/4 of 19 May 1993; E/CN.4/1994/6 of 26 August 1993; E/CN.4/1994/8 of 6 September 1993; E/CN.4/1994/47 of 17 November 1993; E/CNA/ 1994/1 10 of 21 February 1994; E/CN.4/1995/4 of 10 June 1994; E/ CN.4/1995/1 0 of 4 August 1994; A/49/ 641 -S/1 994/1252 of 4 November 1994; E/CN.4/1995/54 of 13 December 1995; E/CN.4/1995/57 of 9 January 1995; E/ CN.4/1996/3 of 21 April 1995; and El CN.4/1996/6 of 5 July 1995 . On'27 July 1995, Mr. Mazowiecki informed the Commission of his decision to resign his mandate. The responsibilities of the Special Rapporteur on the former Yugoslavia were taken up by Ms. Elisabeth Rehn of Finland as of September 1995.

Interim Report of the Commission of Experts Established Pursuant to Security Council Resolution 780 (1992), UN SCOR, Annex 55, UN Doc. 5/25274 (10 Febru- 
ary 1993).

Malcolm, Noel. Bosnia: A Short History, 1994

Magas, Branka. The Destruction of Yugoslavia: Tracing the Break-Up, 1980-92 1993.

Marc Weller. 'The International Response to the Dissolution of the Socialist Federal Republic of Yugoslavia' 86 American Journal of Intemational Law 569 (providing a thorough delineation of the events comprising Yugoslavia's dissolution through mid-1992).

Marc Fisher. 'Slovenia Nears Independence as Croatia Faces Civil War', 6-7 'Leaders Said to See Croats Destined for War.' Washington Post. 20 July 1991.

Moncrieff, Chris. "Lord Owen Sets Off on Peace Trail," Associated Press Newsfile, 30 August 1992.

Morris, Virginia \& Michael P. Scharf. The International Criminal Tribunal for Rwanda. (1998) (Vol. 1) 17.

Paul C. Szašz."Current Development: The Protection of Human Rights Through the Dayton/Paris Peace Agreement on Bosnia." (1996) 90 American Joumal of International Law 301.

,'The Dayton Accord: The Balkan Peace Agreement' 30 Comell Intemational Law Joumal .

Pejic, Jelena, 'Panel II: Adjudicating Violence: Problems Confronting International Law and Policy on War Crimes and - Crimes Against Humanity; The Tribunal And The ICC: Do Precedents Mat- ter?' (1997) 60 Albany Law Review 841.

P J G Kapteyn \& P V Van Themaat. Introduction to the Law of the European Communities After the Coming into Force of the Single European Act. (2nd ed. 1989).

Policing Yugoslavia. Times, London: 31 July 1991.

Report on the Situation of Human Rights in the Territory of the former Yugoslavia submitted by Mr. Tadeusz Mazowiecki, Special Rapporteur of the Commission on Human Rights, pursuant to paragraph 14 of Commission resolution 1992/S-1/1 of 14 August 1992, E/CN.4/ 1992/S-1/9, 28 August 1992.

Riggs, Robert E \& Jack C Plano, The United Nations: Intemational Organization and World Politics, 1988.

SC Res. 652, UN SCOR, 2918th mtg., 652 (1992); SC Res. 727, UN SCOR, 3028th mtg., UN Doc. S/Res/727 (1992); SC Res: 740, UN SCOR, 3049th mtg., UN Doc. S/Res/7/740 (1992); SC Res. 743, UN SCOR, 3055th, mtg., UN Doc. S/Res/ 743 (1992); SC Res. 749; UN SCOR, 3066th mtg., UN Doc.? S/Res/749 (1992); SC Res. 757 UNSCOR, 3082nd mtg., UN Doc. S/Res/757, (1992); SC Res. 762, UN SCOR, 3088th mtg., UN Doc. S/Res/762 (1992); SC Res. 764, UN SCOR, 3093rd mtg., UN Doc. SI $\operatorname{Res} / 764$ (1992).

SC Res. 752, above $n 42$ (expansion of UNPROFOR mandate); SC Res. 757, UN SCOR, 3082th mtg., UN Doc. SI 
Res/760 (1992) (general sanctions imposed); SC Res. 758, UN SCOR, 3083th mtg., UN Doc. (1992); SC Res. 760, UN SCOR, 3086th mtg., UN Doc. S/Res/760 (1992); SC Res. 761, UN SCOR, 3087th mtg., UN Doc. S/Res/ 761 (1992) (demand that äll parties and others concerned co-operate fully with UNPROFOR and international humanitarian agencies and organisations and take all necessary steps to ensure the safety of their personnel); SC Res. 762 , UN SCOR, 3088th mtg., para. 2, UN Doc. S/Res/762 (1992) (expanding UNPROFOR's mandate); SC Res. 764, UN SCOR, 3093rd mtg., UN Doc. SI Res/764 (1992) (authorising UNPROFOR to protect humanitarian assistance); SC Res. 771, UN SCOR, 3106th mtg., UN Doc. Ș/Res/771 (1992).
SC Res 780 (1992) adopted by the Security Council at its 3119th meeting, 6 October 1992. Reprinted in 31 ILM (1992) 1476.

Tanner, Marcus. 'Slovenia is at War,' The Independent. 28 June 1991 at 1.

The Pol Pot Riddl,' The Economist. 28 June 1997 at 47.

The United Nations. and the Situation in the Former Yugoslavia: Resolutions of the Security Council and Statements by its President. 25 September 1991-28 April 1995. (United Nations Department of Public information, 1995).

Thorpe, Nick . "Yugoslavia: Croatia digs in for Long War." Observer. 13 October 1991

UN Doc. S/25274 of 9 February 1993. 